\title{
Plasma protein and supplemental isoleucine in milk replacers for dairy calves
}

\author{
K. M. Vasquez, ${ }^{* 1}$ S. Y. Morrison, ${ }^{*}$ J. M. Campbell, $†$ and J. K. Drackley ${ }^{* 2}$ \\ *Department of Animal Sciences, University of Illinois, Urbana 61801 \\ †APC Inc., 2425 SE Oak Tree Court, Ankeny, IA 50021
}

\section{ABSTRACT}

We measured the effects of milk replacers containing $0,33,66$, or $100 \%$ of the total replaceable whey protein as bovine plasma protein (PP), without or with Ile supplementation, on the intake, growth, and health of 124 male Holstein calves for $35 \mathrm{~d}$. Milk replacers were formulated to contain $18 \%$ crude protein and $20 \%$ fat, with contents of Lys and Met equalized. When fed to calves at $1.5 \%$ of body weight (dry matter basis) under thermoneutral conditions, diets were predicted to allow average daily gains of $0.55 \mathrm{~kg} / \mathrm{d}$ based on metabolizable energy or $0.40 \mathrm{~kg} / \mathrm{d}$ based on apparent digestible protein. Protein supply was more limiting than energy so that differences in protein use could be detected. Dry matter intakes decreased with increased PP, irrespective of Ile supplementation. Final body weights decreased linearly with increasing PP, regardless of Ile supplementation. Average daily gain tended to be affected in a quadratic manner as PP increased, either with or without Ile supplementation; average daily gain and gain-feed ratio were greatest for calves fed diets containing $33 \%$ PP and lowest for calves fed $100 \%$ PP. The analyzed Lys content in the milk replacers was variable compared with formulated values, and this may have affected growth results. However, the gain-Lys ratio was affected by an interaction of the linear effect of increasing PP with Ile supplementation: it decreased with increasing PP but was improved by supplementation with Ile for calves fed $100 \%$ PP. Body measurements decreased with increasing PP inclusion; only decreased heart girth was reversed with Ile supplementation. The lowest and highest inclusion of PP, regardless of Ile supplementation, decreased the occurrence of scours compared with the control diet (all whey protein). Calves fed the lowest and highest PP without Ile supplementation also had fewer total days of scours in the first $21 \mathrm{~d}$. In addition, calves fed $100 \%$

\footnotetext{
Received May 17, 2016.

Accepted October 1, 2016.

${ }^{1}$ Current address: 341 Pine Valley Ct., Linden, MI 48451.

${ }^{2}$ Corresponding author: drackley@illinois.edu
}

PP without supplementation of Ile had fewer days of medication compared with the control diet. Even at the highest PP inclusion, average daily gain was minimally affected if Ile was supplemented. Growth rates, gainfeed ratio, and gain-Lys ratio were decreased at higher PP inclusion, but Ile overcame part of the reduction in gain-Lys ratio for $100 \%$ PP. Additional titration studies will have to be conducted to determine optimal PP inclusion rates, with a focus on supplementation of potentially limiting essential AA, as well as effects at higher growth rates.

Key words: calf, milk replacer, plasma protein, amino acids

\section{INTRODUCTION}

In the United States, over $85 \%$ of heifers are fed milk replacer (MR) for at least a portion of the preweaning period (USDA, 2012). In MR formulation, protein ingredients represent a major proportion of the cost. Whey proteins have become the standard for all-milkprotein MR, because they are highly digestible and contain a satisfactory AA profile when supplemented with Met (Davis and Drackley, 1998). However, depending on the market, milk-derived proteins can be expensive to include in calf MR. As a result, research has focused on finding alternative protein sources for MR that will promote calf performance similar to milk-derived proteins.

Spray-dried plasma proteins $(\mathbf{P P})$ are good sources of EAA, with the exception of Lys, Met, and Ile, and are processed to maintain the functional characteristics of proteins, including albumin and IgG. Plasma proteins have been evaluated in calf MR and have been shown to provide similar (Quigley and Bernard, 1996; Quigley and Wolfe, 2003) or improved (Morrill et al., 1995; Quigley et al., 2002) performance compared with all-milk-protein MR. In previous studies, researchers have replaced up to $25 \%$ of total milk CP with PP, but MR with more than $25 \%$ of $\mathrm{CP}$ replaced by $\mathrm{PP}$ have not been evaluated. As a result, the upper limit of successful inclusion of PP in calf MR is unknown. In weanling pig diets, PP supplements are widely used; 
research has shown that inclusion at up to $6 \%$ of the total diet increases ADG and average daily feed intake in the first $2 \mathrm{wk}$ after weaning, and improves the feed conversion ratio (van Dijk et al., 2001). Our objective in this experiment was to determine the effects of MR containing 0 to $100 \%$ of the total replaceable milk protein as bovine PP, without or with supplemental Ile, on calf growth and health.

\section{MATERIALS AND METHODS}

\section{Calves, Arrival, and Housing}

All procedures were conducted under protocols approved by the University of Illinois Institutional Animal Care and Use Committee. Four groups of 31 male Holstein calves, less than 1 wk old, were purchased from sale barns in Wisconsin or New York and transported to the University of Illinois Nutrition Field Laboratory research site. The first 2 groups arrived in July and September 2009, respectively; the third and fourth groups were purchased in March and June 2010, respectively. Upon arrival, calves were fed $4 \mathrm{~L}$ of electrolyte solution (Land O'Lakes Electrolyte System; Land O'Lakes Inc., Saint Paul, MN). Each calf was vaccinated with TSV2 (Pfizer Inc., New York, NY), administered ceftiofur crystalline free acid (Excede, Pfizer Inc.) and seleniumvitamin E (MuSe, Intervet Schering-Plough Animal Health, Union, NJ), and had its naval dipped with povidone iodine (Durvet Inc., Blue Springs, MO). Blood was sampled via jugular venipuncture into a $10-\mathrm{mL}$ evacuated serum separation tube (Becton Dickinson, Rutherford, NJ) to estimate serum protein concentration using a refractometer. Blood sampling time was $\sim 1$ $\mathrm{h}$ after administration of electrolytes and was similar for all calves. Remaining serum was divided into aliquots and stored in polypropylene tubes at $-20^{\circ} \mathrm{C}$ until it was analyzed for total IgG concentration.

Calves were housed in south-facing individual hutches (Calf-tel; Hampel Corp., Germantown, WI) placed 1.5 $\mathrm{m}$ from one another. Hutches were placed on crushed limestone, which was covered by landscape cloth (DuPont) and a layer of straw. Straw bedding was checked daily, and additional straw was added as needed for each calf.

\section{Feeding and Management of Calves}

Calves were blocked on the day of arrival (d 0) by BW and serum protein concentration, and then randomly assigned within each block to 1 of $7 \mathrm{MR}$ treatments (Table 1) that contained increasing amounts of PP (NutraPro B, APC Inc., Ankeny, IA) without or with supplemental Ile. Treatments were control, all-milkprotein MR (0PP); $33 \%$ PP addition (33PP); $33 \%$ $\mathrm{PP}$ addition plus Ile to equalize to diet $0 \mathrm{PP}(\mathbf{3 3 P P}+)$; $66 \% \mathrm{PP}$ addition (66PP); $66 \% \mathrm{PP}$ addition plus Ile to equalize to diet $0 \mathrm{PP}(\mathbf{6 6 P P}+) ; 100 \%$ PP addition (100PP); and 100\% PP addition plus Ile to equalize to diet 0PP $(\mathbf{1 0 0 P P}+)$. Milk replacers were manufactured by Milk Specialties Co. (Eden Prairie, MN).

The isonitrogenous diets were formulated to contain $18 \%$ CP, $20 \%$ fat, $1.75 \%$ Lys, and $0.51 \%$ Met. The formulation strategy was to increase PP incrementally until it replaced all whey proteins, with the exception of the whey proteins provided in the spray-dried, protein-encapsulated fat. The maximum amount of whey proteins replaced in the $100 \% \mathrm{PP}$ formulas $(100 \mathrm{PP}$ and $100 \mathrm{PP}+$ ) was approximately $88 \%$. Lactose was added to maintain its content in the $100 \% \mathrm{PP}$ diets, because dried whey and whey protein concentrate were removed.

In formulation of the diets, AA balance was considered using the ideal protein concept, in which the EAA are expressed relative to Lys content as the reference AA. The target profile for growth used was an unpublished estimate from M. E. Van Amburgh (Cornell University, Ithaca, NY). This profile was determined from whole-body AA composition of 65- and 105-kg preruminant Holstein calves (Van Amburgh et al., 2015) and is generally consistent with the earlier profile estimate from Williams and Hewitt (1979). Lysine was provided in the control diet entirely from the whey proteins, whereas L-Lys $\mathrm{HCl}$ was added to diets containing PP to equalize Lys content to control values. Supplemental DL-Met was added to all diets to bring the formulated Met content to $0.51 \%$. For diets with supplemental Ile, we aimed to equalize its content with that in the control (0PP) diet. Dietary contents of the remaining AA were determined by their content in whey protein and PP.

Calves were fed MR (reconstituted to $12.5 \%$ solids) twice daily at 0530 and $1630 \mathrm{~h}$ for 5 wk. During wk 1 , calves were fed at a rate of $1.25 \%$ of BW (DM basis) and during wk 2 to 5 , calves were fed at a rate of $1.5 \%$ of BW. The amount fed was updated weekly based on BW. Diets fed at this rate were predicted to provide allowable gains of $0.55 \mathrm{~kg} / \mathrm{d}$ based on $\mathrm{ME}$ and $0.40 \mathrm{~kg} / \mathrm{d}$ based on apparent digestible protein for a $50-\mathrm{kg}$ calf under thermoneutral conditions (NRC, 2001). The average mean temperature for the first 2 groups of calves was $20^{\circ} \mathrm{C}$, and for the second 2 groups of calves it was $15.5^{\circ} \mathrm{C}$ (www.wunderground.com), which is within the thermoneutral zone of young calves (NRC, 2001).

Intake of MR was recorded daily. Water was offered ad libitum, and intake was recorded daily. Starter was not offered during the study. Body weight, heart girth, and withers height were measured upon arrival and 
weekly for the duration of the trial at the same time on the same day each week.

\section{Health}

Calf health was monitored several times daily, and health scores were recorded once daily. Fecal scores were assigned on a scale of 1 to $4: 1=$ normal and well formed; 2 = soft, but still holds form; 3 = loose, without form; and $4=$ consistency of water. Respiratory scores were assigned on a scale of 1 to 5 : $1=$ normal; 2 = open-mouth breathing; $3=$ open-mouth breathing with mucus; $4=$ dry cough; and $5=$ wet cough. Calves were considered to have scours if the fecal score was $>2$ and respiratory illness if the respiratory score was $>1$. Rectal temperatures were recorded daily for every calf in wk 1 , and thereafter for calves showing signs of illness. Flunixin meglumine (FluMeglumine, Phoenix Pharmaceuticals Inc., Burlingame, CA) was administered to calves with a rectal temperature of $40^{\circ} \mathrm{C}$ or above. Hydration status was assessed using fecal scores, skin tent test, eye appearance, and overall attitude. An electrolyte solution (Land O'Lakes Electrolyte System; Land O'Lakes, Inc.) was administered as needed. All calves were vaccinated according to facility protocols.

\section{Blood Collection and Analysis}

Blood was sampled at arrival and during wk 4 at $0800 \mathrm{~h}$, which was about $2.5 \mathrm{~h}$ after the morning feeding. Blood was obtained via jugular venipuncture into $10 \mathrm{~mL}$ evacuated serum separation tubes (Becton Dick-

Table 1. Ingredient and formulated chemical composition of milk replacer treatments (\% of DM unless otherwise noted)

\begin{tabular}{|c|c|c|c|c|c|c|c|}
\hline \multirow[b]{2}{*}{ Component } & \multicolumn{7}{|c|}{ Treatment $^{1}$} \\
\hline & $0 \mathrm{PP}$ & $33 \mathrm{PP}$ & $33 \mathrm{PP}+$ & $66 \mathrm{PP}$ & $66 \mathrm{PP}+$ & $100 \mathrm{PP}$ & $100 \mathrm{PP}+$ \\
\hline \multicolumn{8}{|l|}{ Ingredient, $\%$ as is } \\
\hline Dried whey powder & 53.82 & 53.41 & 53.38 & 45.32 & 43.46 & 2.56 & - \\
\hline Whey protein concentrate, $75.0 \% \mathrm{CP}$ & 12.94 & 5.82 & 5.67 & - & - & - & - \\
\hline Lactose & - & - & - & 6.34 & 7.82 & 41.27 & 43.31 \\
\hline Protein-encapsulated fat $^{2}$ & 29.74 & 30.43 & 30.44 & 31.07 & 31.09 & 31.54 & 31.57 \\
\hline Emulsifier $^{3}$ & 1.00 & 1.00 & 1.00 & 1.00 & 1.00 & 1.00 & 1.00 \\
\hline Minerals, vitamins, and flavor & 1.73 & 1.73 & 1.73 & 1.73 & 1.73 & 1.73 & 1.73 \\
\hline Dicalcium phosphate & 0.62 & 0.42 & 0.42 & 0.41 & 0.47 & 1.30 & 1.38 \\
\hline Limestone & - & 0.22 & 0.22 & 0.36 & 0.34 & 0.17 & 0.14 \\
\hline Spray-dried bovine plasma protein ${ }^{4}$ & - & 6.63 & 6.63 & 13.27 & 13.27 & 19.90 & 19.90 \\
\hline L-Lys $\mathrm{HCl}$ & - & 0.13 & 0.14 & 0.23 & 0.25 & 0.21 & 0.24 \\
\hline DL-Met & 0.14 & 0.21 & 0.21 & 0.27 & 0.28 & 0.32 & 0.32 \\
\hline Ile & - & - & 0.15 & - & 0.30 & - & 0.41 \\
\hline \multicolumn{8}{|l|}{ Nutrient } \\
\hline $\mathrm{CP}, \%$ & 18.4 & 18.4 & 18.4 & 18.4 & 18.4 & 18.4 & 18.4 \\
\hline Crude fat, $\%$ & 20.0 & 20.0 & 20.0 & 20.0 & 20.0 & 20.0 & 20.0 \\
\hline Gross energy, kcal/kg & 4,716 & 4,699 & 4,698 & 4,717 & 4,723 & 4,891 & 4,900 \\
\hline Lactose $\%$ & 45.4 & 45.0 & 45.0 & 45.4 & 45.6 & 49.8 & 50.0 \\
\hline $\mathrm{Ca}, \%$ & 1.04 & 1.04 & 1.04 & 1.04 & 1.04 & 1.04 & 1.04 \\
\hline $\mathrm{P}, \%$ & 0.70 & 0.70 & 0.70 & 0.70 & 0.70 & 0.70 & 0.70 \\
\hline Lys, \% & 1.75 & 1.75 & 1.75 & 1.75 & 1.75 & 1.75 & 1.75 \\
\hline Met, \% & 0.51 & 0.51 & 0.51 & 0.51 & 0.51 & 0.51 & 0.51 \\
\hline Ile, $\%$ & 1.12 & 0.98 & 1.12 & 0.84 & 1.12 & 0.73 & 1.12 \\
\hline Thr, \% & 1.22 & 1.16 & 1.15 & 1.12 & 1.10 & 1.14 & 1.12 \\
\hline His, $\%$ & 0.30 & 0.40 & 0.40 & 0.50 & 0.50 & 0.60 & 0.60 \\
\hline Leu, \% & 1.89 & 1.84 & 1.83 & 1.80 & 1.78 & 1.82 & 1.79 \\
\hline Val, $\%$ & 1.06 & 1.09 & 1.08 & 1.13 & 1.12 & 1.21 & 1.19 \\
\hline Phe, \% & 0.58 & 0.71 & 0.71 & 0.84 & 0.84 & 1.00 & 0.99 \\
\hline $\operatorname{Trp}, \%$ & 0.31 & 0.32 & 0.32 & 0.33 & 0.33 & 0.34 & 0.34 \\
\hline Arg, \% & 0.50 & 0.67 & 0.67 & 0.84 & 0.83 & 1.01 & 1.00 \\
\hline Cys, \% & 0.54 & 0.53 & 0.53 & 0.54 & 0.54 & 0.62 & 0.61 \\
\hline Tyr, \% & 0.52 & 0.61 & 0.60 & 0.69 & 0.68 & 0.79 & 0.78 \\
\hline Met + Cys, $\%$ & 1.05 & 1.04 & 1.04 & 1.05 & 1.04 & 1.13 & 1.12 \\
\hline Phe + Tyr $\%$ & 1.10 & 1.32 & 1.31 & 1.54 & 1.52 & 1.79 & 1.77 \\
\hline
\end{tabular}

${ }^{1}$ Treatments: $0 \mathrm{PP}=$ control; $33 \mathrm{PP}=33 \%$ spray-dried bovine plasma protein $(\mathrm{PP}) ; 33 \mathrm{PP}+=33 \% \mathrm{PP}+\mathrm{Ile} ; 66 \mathrm{PP}=66 \% \mathrm{PP} ; 66 \mathrm{PP}+=66 \%$ $\mathrm{PP}+$ Ile $; 100 \mathrm{PP}=100 \% \mathrm{PP} ; 100 \mathrm{PP}+=100 \% \mathrm{PP}+$ Ile.

${ }^{2}$ Contained $7 \%$ protein (from whey sources) and $60 \%$ fat (proprietary mixture of tallow, lard, and coconut oil).

${ }^{3}$ Blend of lecithin, lard, and polyethylene glycol.

${ }^{4}$ NutraPro B (APC Inc., Ankeny, IA). 
inson). Blood was centrifuged at 1,300 $\times g$ for $15 \mathrm{~min}$. Serum was divided into aliquots in polypropylene tubes and stored at $-20^{\circ} \mathrm{C}$ until analysis.

Serum from the samples at arrival was analyzed for total IgG by radial-immunodiffusion. Samples from wk 4 were analyzed for concentrations of urea $\mathrm{N}$, total protein, and albumin. Total globulin was calculated as the difference between total protein and albumin. All analyses were conducted at the University of Illinois College of Veterinary Medicine diagnostic laboratory (Urbana, IL) using automated enzymatic analysis procedures.

\section{Milk Replacer Sampling and Analysis}

We sampled MR daily and stored them at $-20^{\circ} \mathrm{C}$ until analysis. Composite samples were prepared for each batch of calves and analyzed by Dairy One Laboratory (Ithaca, NY) for DM, CP, soluble protein, crude fat, ash, $\mathrm{Ca}, \mathrm{P}, \mathrm{Mg}, \mathrm{K}, \mathrm{Na}, \mathrm{Fe}, \mathrm{Zn}, \mathrm{Cu}, \mathrm{Mn}, \mathrm{S}$, and $\mathrm{Mo}$ by standard wet chemistry methods (www.dairyone.com/ Forage/Procedures/default.htm). Samples also were sent to the University of Missouri Agricultural Experiment Station Laboratory (Columbia, MO) for complete AA analysis by cation-exchange chromatography coupled with post-column ninhydrin derivatization and quantification. Tryptophan content was determined by base-catalyzed hydrolysis. Estimated ME content of diets was calculated according to NRC (2001) from analyzed nutrient content of diets.

\section{Statistical Analysis}

Analysis of variance was conducted using the MIXED procedure in SAS (v 9.3; SAS Institute Inc., Cary, NC). Calf, block, and batch were defined as random effects; treatment was a fixed effect. For variables with repeated measurements, a covariate (initial measurement) was used, and data were analyzed with week and treatment by week in the model with calf as the subject. Initial BW, heart girth, and withers height were used as covariates for the respective measurements. Treatment comparisons were made using 6 preplanned, nonorthogonal contrasts: (1) the linear effect of increasing PP without supplemental Ile; (2) the quadratic effect of increasing PP without supplemental Ile; (3) the linear effect of increasing PP with supplemental Ile; (4) the quadratic effect of increasing PP with supplemental Ile; (5) the overall effect of addition of supplemental Ile; and (6) the interaction of the linear effect of increasing PP with addition of Ile. Models for the occurrence of scours and treatment with antibiotics were evaluated by logistic regression using a binomial distribution in the GLIMMIX procedure in SAS. Duration of scouring and administration of medication were evaluated with a Poisson distribution using the GENMOD procedure in SAS. Significance was declared at $P \leq 0.05$, and trends are discussed when $P \leq 0.10$. Least squares means were calculated and are presented with standard errors.

\section{RESULTS}

\section{Nutrient Composition of Diets}

The analyzed chemical composition of the MR is shown in Table 2. All diets were formulated to contain $\sim 18 \%$ CP so that protein supply was predicted to be more limiting than energy supply (NRC, 2001) as a way of maximizing the ability to detect differences in dietary protein use among treatments. The measured CP (\% of DM) contents ranged from $19.7 \%$ for the 0PP and $66 \mathrm{PP}+$ diets to a low of $17.2 \%$ for the $100 \mathrm{PP}+$ diet. Contents of ash and K were lower for the $100 \%$ PP diets without or with Ile because the dried whey was replaced by lactose and $\mathrm{PP}$.

The AA analyses of the MR on a DM basis are shown in Table 3. Treatments were formulated to contain $1.75 \%$ Lys. The analyzed Lys content was $1.68 \%$ for control and ranged from a high of $1.92 \%$ for $66 \mathrm{PP}$ to a low of $1.50 \%$ for $100 \mathrm{PP}+$. The Met content ranged from 0.40 to $0.48 \%$ of dietary DM. Supplementation with Ile increased its content over the corresponding unsupplemented PP diets, but analyzed Ile remained slightly lower than control for diets containing PP. The CV for AA analyses were generally higher for AA that were supplemented in crystalline form (Lys, Met, and Ile) than for those provided entirely by dietary proteins, as might be expected (Table 3).

The AA profile relative to Lys content $($ Lys $=100)$ is shown in Table 4. Methionine was formulated at $29 \%$ of Lys (i.e., $0.51 \%$ of dietary DM). The analyzed Met content was $24 \%$ of Lys for control and ranged from $23 \%$ of Lys for $33 \mathrm{PP}+$ to $27 \%$ for $33 \mathrm{PP}$ and $66 \mathrm{PP}$. Differences in actual ratios relative to formulated ratios were attributable to variation in both analyzed Lys and the respective AA.

\section{Intakes}

Mean intakes of DM, CP, ME, and Lys are shown in Table 5. Dry matter intake decreased with increasing addition of PP, with or without supplemented Ile (contrast $1, P=0.008$; contrast $3, P=0.05$, respectively). When weeks were examined individually (data not shown), the linear effect on DMI of increasing PP in Ile-supplemented diets was significant during wk 3,4 , 
Table 2. Analyzed chemical composition of experimental milk replacers

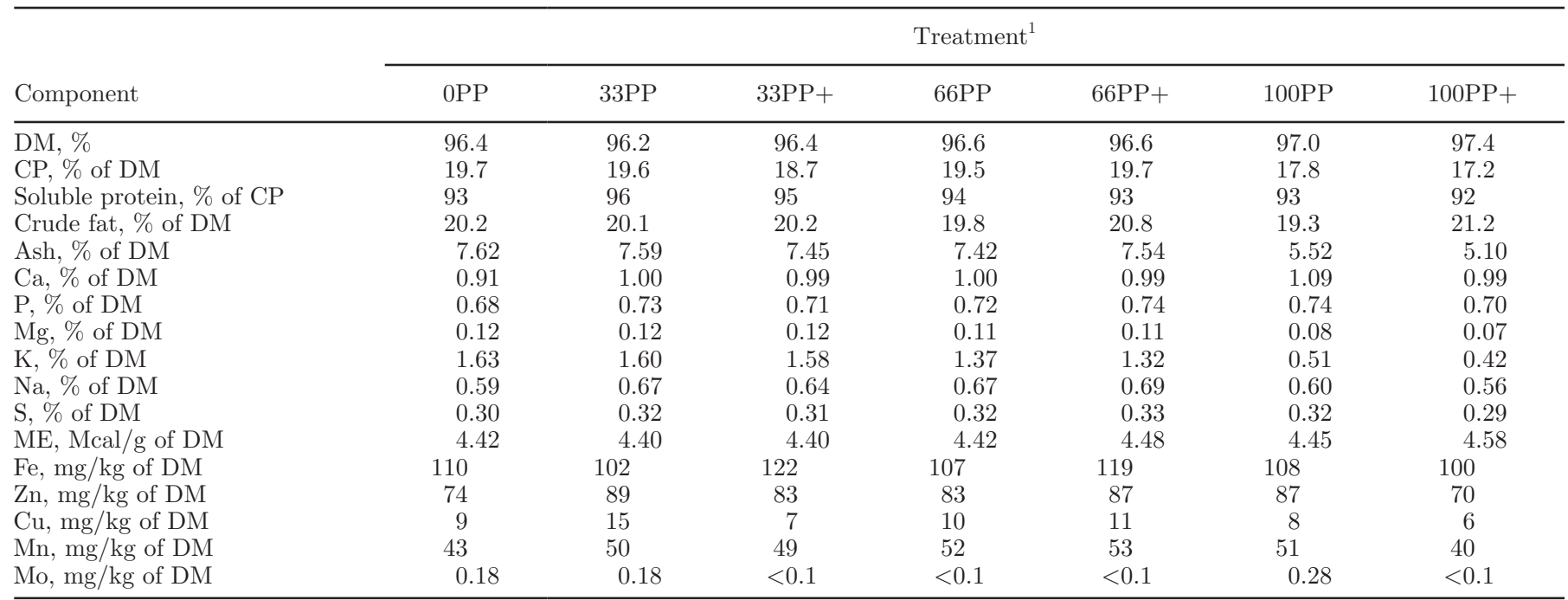

${ }^{1}$ Treatments: $0 \mathrm{PP}=$ control; $33 \mathrm{PP}=33 \%$ spray-dried bovine plasma protein $(\mathrm{PP}) ; 33 \mathrm{PP}+=33 \% \mathrm{PP}+\mathrm{Ile} ; 66 \mathrm{PP}=66 \% \mathrm{PP} ; 66 \mathrm{PP}+=66 \%$ $\mathrm{PP}+$ Ile $; 100 \mathrm{PP}=100 \% \mathrm{PP} ; 100 \mathrm{PP}+=100 \% \mathrm{PP}+$ Ile.

and 5, as DMI decreased with increasing PP. However, we observed no significant treatment effects on ME intake, likely attributable to increased variation when combining intakes and nutrient analysis to estimate ME intake.

Differences in CP and Lys intakes reflect small differences in DMI and differences in analyzed CP content among the diets. Mean CP intakes decreased in a quadratic manner as PP increased, either with or without supplemental Ile (contrast $2, P=0.004$; contrast $4, P$ $=0.02$, respectively). The addition of Ile to diets with $\mathrm{PP}$ resulted in lower average $\mathrm{CP}$ intake (contrast $5, P$ $<0.001)$. The quadratic effect of increasing PP without supplemental Ile on Lys intake approached significance (contrast 2, $P=0.09$ ). The linear and quadratic effects of increasing PP with supplemental Ile were significant (contrasts 3 and $4, P<0.0001$ ) for overall Lys intake. The interaction of the linear effect of increasing $\mathrm{PP}$ and Ile supplementation was significant (contrast $6, P$ $<0.001$ ), indicating that decreases in Lys intake for Ile-supplemented diets became larger as the amount of PP increased.

\section{Growth and Efficiency}

Means for BW, ADG, and feed efficiency measurements are presented in Table 5. Initial BW did not differ among treatments. Final BW decreased linearly as PP increased in diets without or with Ile supplementation (contrast $1, P<0.001$; contrast $3, P<0.001$ ). The ADG decreased linearly as PP increased, regardless of Ile supplementation (contrast $1, P<0.001$; contrast
$3, P<0.001)$, and the quadratic effect of increasing PP approached significance for both nonsupplemented (contrast 2, $P=0.07$ ) and Ile-supplemented (contrast $4, P=0.06)$ diets. On average, Ile supplementation increased gain-feed ratio means, but the values did not achieve statistical significance (contrast $5, P=0.13$ ). The ratio of gain to Lys intake decreased linearly with increasing PP, without supplemental AA (contrast 1, $P<0.001$ ) or with it (contrast $3, P<0.001$ ). The significant interaction of the linear effect of increasing $\mathrm{PP}$ with addition of Ile (contrast $6, P=0.05$ ) showed that Ile improved gain-Lys ratio for $100 \mathrm{PP}+$.

Initial body conformation measurements did not differ significantly among treatments (data not shown). Final heart girth (Table 5) decreased linearly as PP increased in either nonsupplemented or Ile-supplemented diets (contrasts 1 and $3, P<0.001$ ). The effect of Ile supplementation approached significance (contrast 5 , $P=0.06$ ) for final heart girth. The average gain of heart girth decreased linearly in the supplemented and nonsupplemented groups as PP increased (contrast 1 and contrast $3, P<0.001$ ), although the effect tended to be quadratic in the nonsupplemented diets (contrast 2, $P=0.08)$.

Final withers height (Table 5) decreased linearly in both nonsupplemented and Ile-supplemented calves as dietary PP increased (contrast $1, P<0.001$; contrast $3, P=0.005$ ). Daily gain of withers height decreased quadratically as $\mathrm{PP}$ increased in nonsupplemented diets (contrast $2, P=0.04$ ). The quadratic effects showed that decreases in height gain were larger at higher levels of PP inclusion. The significant interaction of the linear 


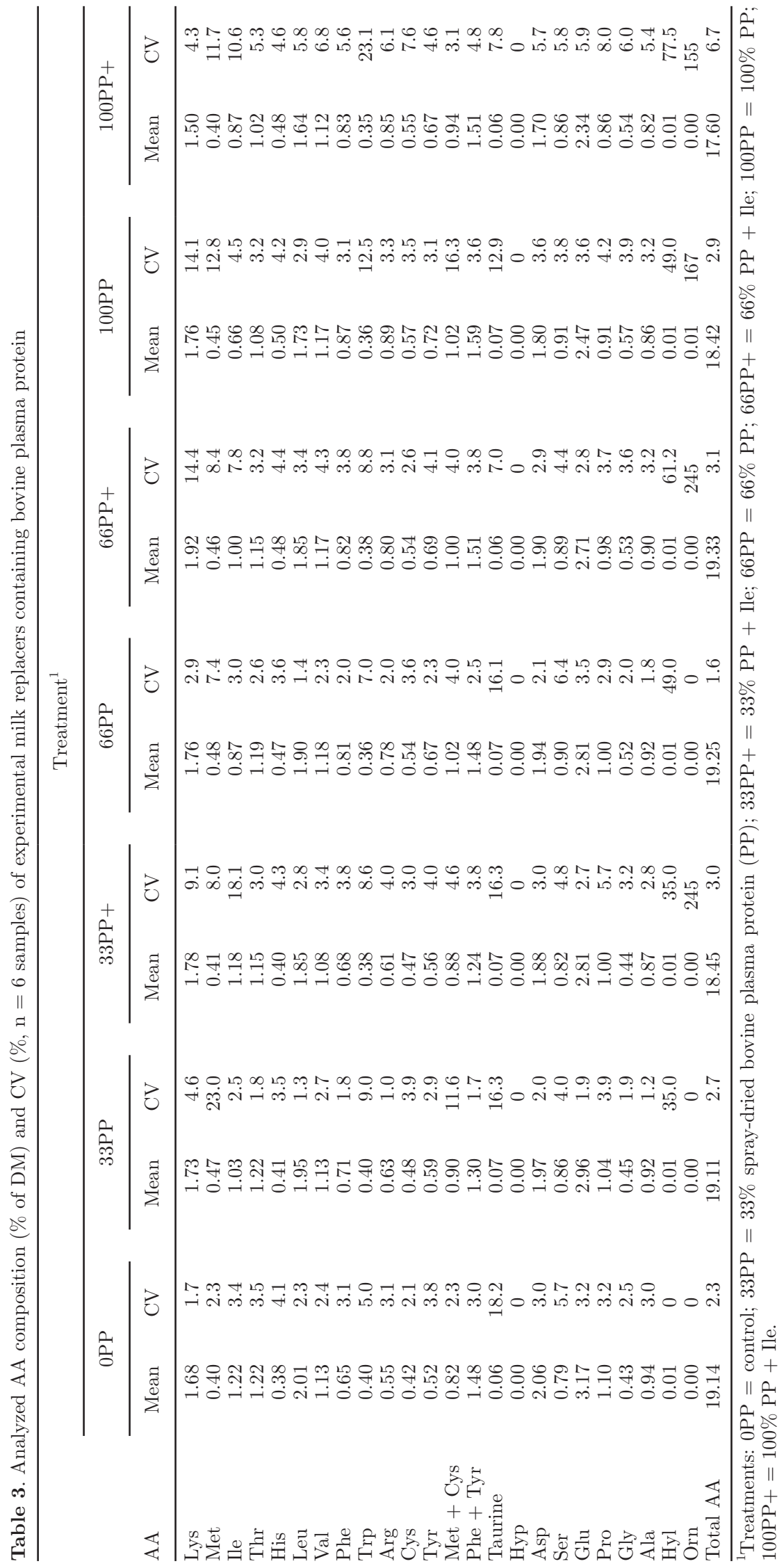


effects of PP and Ile supplementation showed that the decreases in height gain as PP increased were larger in the absence of supplemental Ile.

\section{Blood Metabolites}

The response of urea N (Table 5) in serum to increasing PP was quadratic for diets supplemented with Ile (contrast $4, P=0.02$ ), with the highest concentrations occurring in calves fed $66 \mathrm{PP}+$ and the lowest with calves fed $100 \mathrm{PP}+$. The interaction of the linear effect of increasing PP and Ile supplementation was significant, because urea $\mathrm{N}$ in calves fed the nonsupplemented diets did not increase as much for $66 \mathrm{PP}$ and did not decrease for 100PP; urea $\mathrm{N}$ decreased for $100 \mathrm{PP}+$. We observed only small differences of questionable biological impact among diets for concentrations of total protein, albumin, and globulin in serum (data not shown).

\section{Health}

Overall, 11 calves died during the study: 2 each from $0 \mathrm{PP}, 33 \mathrm{PP}, 33 \mathrm{PP}+, 66 \mathrm{PP}$, and $66 \mathrm{PP}+$, and 1 calf from $100 \mathrm{PP}+$. No calves died in treatment 100PP. The mean $\mathrm{IgG}$ concentrations on the day of arrival did not differ significantly among groups (data not shown) and were above $10 \mathrm{~g} / \mathrm{L}$ for all treatments. We observed no significant effects of diets on body temperature during the first week (data not shown). The addition of Ile resulted in decreased average electrolyte intakes for diets containing PP (contrast 5, $P=0.04$ ). Calves on treatments $33 \mathrm{PP}+, 66 \mathrm{PP}+$, and $100 \mathrm{PP}+$ were given less electrolyte solution than $33 \mathrm{PP}, 66 \mathrm{PP}$, and $100 \mathrm{PP}(0.05$, 0.24 , and 0.04 vs. $0.28,0.27$, and $0.64 \mathrm{~L} / \mathrm{d}$, respectively)

Table 6 shows the logistic models for the occurrence of scours (score $\geq 3$ ) and medication with antibiotics. In the first $21 \mathrm{~d}$, scours occurrence was higher in treatment $0 \mathrm{PP}$ than treatments $33 \mathrm{PP}, 33 \mathrm{PP}+, 100 \mathrm{PP}$, and $100 \mathrm{PP}+$ (odds ratios $=1.37, P<0.0001 ; 1.16, P=$ $0.02 ; 1.19, P=0.008 ; 1.44, P<0.001$, respectively). We observed as no difference among treatments for frequency of medication or respiratory occurrence (data not shown).

Table 7 shows the logistic model for the number of days with scours. All treatments were compared with control (0PP), and calves on treatments 33PP and $100 \mathrm{PP}+$ had fewer days of scours $(8.5 \mathrm{~d}, P=0.002$, and $8.5 \mathrm{~d}, P=0.002$, respectively). We used contrast statements to compare treatment means (Table 7). For days with scours, the contrast of the quadratic effect of increasing PP without supplemental Ile was significant $(P=0.003)$. The contrast of the linear effect of increasing PP with supplemental Ile was significant $(P$ $=0.01)$, with a tendency $(P=0.10)$ for a quadratic effect. The effect of addition of supplemental Ile was significant $(P=0.01)$, with supplemented calves having fewer days with scours.

The logistic model for the number of days of medication with antibiotics is also shown in Table 7 . When compared with treatment $0 \mathrm{PP}$, calves fed treatment $100 \mathrm{PP}+$ had fewer $(P=0.03)$ days of medication $(2.8$ vs. $1.7 \mathrm{~d}$, respectively). Additionally, there tended ( $P=$ $0.09)$ to be an interaction of the linear effect of increasing $\mathrm{PP}$ with addition of Ile.

Table 4. Ratio of analyzed AA to Lys (\% of Lys) in experimental milk replacer treatments compared with target profile and profile of whole milk protein

\begin{tabular}{|c|c|c|c|c|c|c|c|c|c|}
\hline $\mathrm{AA}$ & Target $^{1}$ & $\begin{array}{l}\text { Whole } \\
\text { milk }^{2}\end{array}$ & \multicolumn{7}{|c|}{ Treatment $^{3}$} \\
\hline Lys & 100 & 100 & 100 & 100 & 100 & 100 & 100 & 100 & 100 \\
\hline Ile & 47 & 70 & 73 & 60 & 66 & 50 & 52 & 38 & 58 \\
\hline Thr & 62 & 55 & 73 & 71 & 65 & 68 & 60 & 62 & 68 \\
\hline His & 39 & 32 & 22 & 24 & 22 & 27 & 25 & 29 & 32 \\
\hline Phe & 58 & 58 & 39 & 41 & 38 & 46 & 43 & 49 & 55 \\
\hline $\operatorname{Trp}$ & 18 & 17 & 24 & 23 & 21 & 20 & 20 & 21 & 23 \\
\hline Arg & 106 & 43 & 33 & 37 & 34 & 44 & 42 & 51 & 57 \\
\hline Cys & 26 & 9 & 25 & 28 & 26 & 31 & 28 & 33 & 36 \\
\hline Tyr & 41 & 61 & 31 & 34 & 32 & 38 & 36 & 41 & 45 \\
\hline Met + Cys & 55 & 40 & 49 & 60 & 50 & 57 & 57 & 58 & 62 \\
\hline Phe + Tyr & 99 & 119 & 70 & 75 & 70 & 84 & 79 & 90 & 99 \\
\hline
\end{tabular}

${ }^{1}$ Based on whole-body AA composition of preruminant Holstein calves (Van Amburgh et al., 2015).

${ }^{2}$ From Williams and Hewitt (1979).

${ }^{3}$ Treatments: $0 \mathrm{PP}=$ control; $33 \mathrm{PP}=33 \%$ spray-dried bovine plasma protein $(\mathrm{PP}) ; 33 \mathrm{PP}+=33 \% \mathrm{PP}+\mathrm{Ile} ; 66 \mathrm{PP}=66 \% \mathrm{PP} ; 66 \mathrm{PP}+=66 \%$ $\mathrm{PP}+\mathrm{Ile} ; 100 \mathrm{PP}=100 \% \mathrm{PP} ; 100 \mathrm{PP}+=100 \% \mathrm{PP}+$ Ile. 
VASQUEZ ET AL.

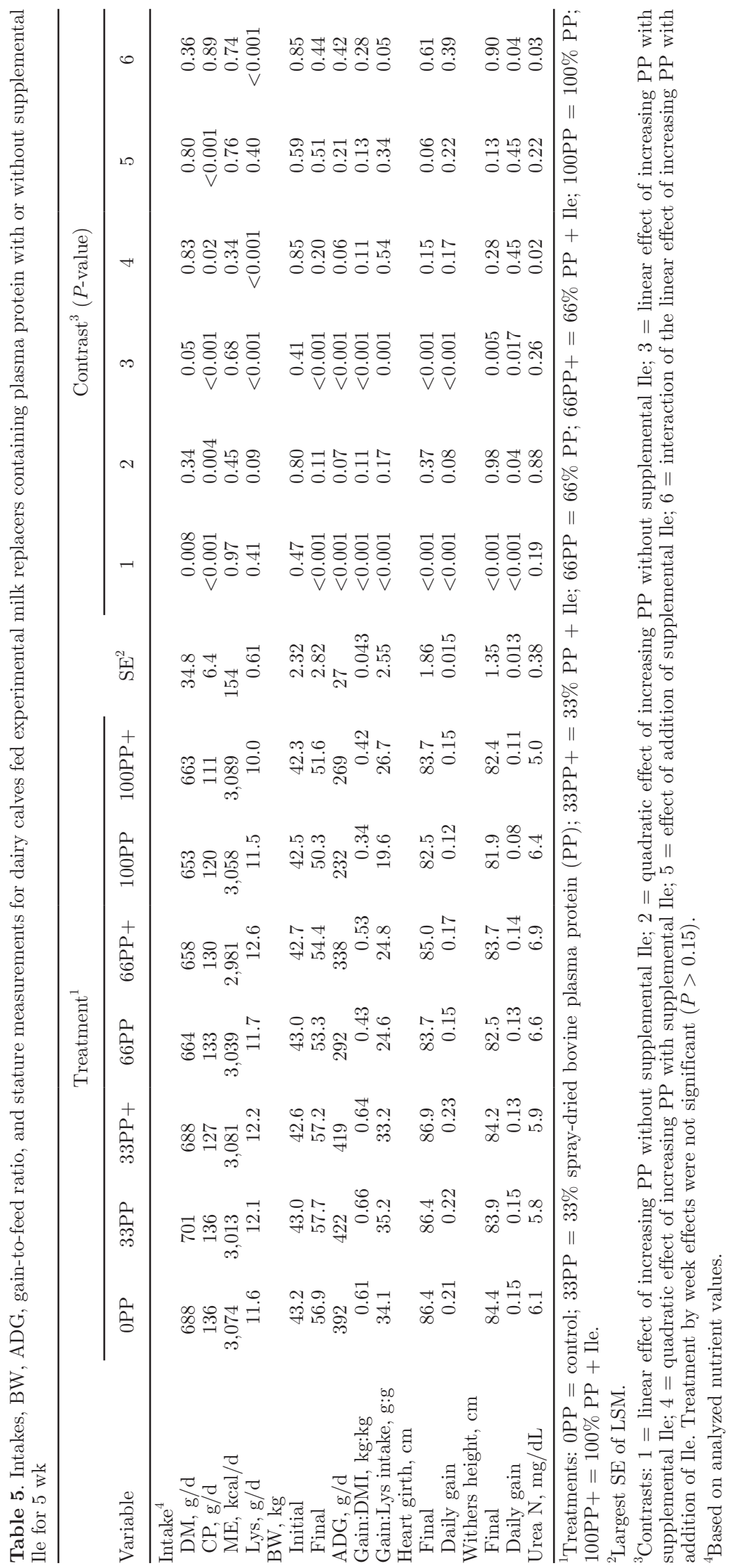




\section{DISCUSSION}

The goal of the current trial was to determine responses to inclusion levels of PP that were greater than in previous studies, with up to $100 \%$ of the total replaceable CP supplied by PP. Previous research investigated $\mathrm{PP}$ inclusion rates of $<25 \%$ of the dietary $\mathrm{CP}$, less than the $33 \%$ of dietary CP that was the lowest supplementation rate in our study. We observed decreased BW, $\mathrm{ADG}$, gain-feed ratio, and stature measurements as the percentage of PP increased in the diet. However, as demonstrated in previous studies, calves fed the diets containing the lowest amount of protein replaced by PP had growth performance that was similar to calves fed the all-milk-protein control diet. Quigley and Bernard (1996) observed that growth performance in calves fed $\mathrm{MR}$ in which spray-dried plasma provided $25 \%$ of the protein was similar to calves fed all whey proteins. Morrill et al. (1995) observed improved performance when calves were fed a diet providing $25 \%$ of the protein as spray-dried plasma. Therefore, our results agree with previous research for low levels of PP supplementation to calves fed for modest growth rates.

Although growth was lower for calves fed the diets with the greatest amount of milk protein replacement by PP, the relative decrease was smaller when Ile was supplemented. Calves obviously tolerated this degree of milk protein replacement because their health was equal to or better than that of the calves fed the allmilk control and to those fed lower supplementation rates of PP. To our knowledge, our results represent the greatest degree of milk or whey protein replacement in diets for very young calves, in which growth and health were not severely compromised. Such results seem to indicate that, as a milk protein replacement, PP should be considered differently from other alternative proteins, such as soy or other legume sources (Davis and Drackley, 1998). Reasons why growth and gain-feed ratio were decreased as PP increased are unclear, but may be related at least in part to the variance in actual AA concentrations compared with target values.

The feeding rate and diet composition used in this study aimed to ensure that allowable growth based on apparent digestible protein was more limiting than allowable growth based on ME, according to NRC (2001) model predictions. We reasoned that, under such conditions, differences in protein digestibility or AA balance should result in decreased growth. Actual ADG for calves fed 0PP, 33PP, or $33 \mathrm{PP}+(392,422$, and 419 $\mathrm{g} / \mathrm{d}$, respectively) were close to the predicted allowable growth rate based on apparent digestible protein (400 $\mathrm{g} / \mathrm{d}$ ) and substantially lower than the predicted allowable growth rate based on ME of $550 \mathrm{~g} / \mathrm{d}$, verifying that our desired experimental conditions were achieved. Lower growth rates for calves fed the diets containing $66 \%$ or $100 \%$ PP (without or with Ile) were consistent with some factor or factors limiting AA availability or use relative to NRC (2001) predictions.

Some of the differences in ADG may have been related to variations in Lys concentration in the diets,

Table 6. Logistic model for scours occurrence ${ }^{1}$ from d 1 to 21 in dairy calves by comparison of experimental treatments

\begin{tabular}{|c|c|c|c|c|c|}
\hline Treatment comparison $^{2}$ & Coefficient & SEM & Odds ratio $^{3}$ & $95 \% \mathrm{CI}$ & $P$-value \\
\hline $0 \mathrm{PP}$ vs. $33 \mathrm{PP}$ & 0.311 & 0.074 & 1.37 & $1.18,1.58$ & $<0.001$ \\
\hline $0 \mathrm{PP}$ vs. $33 \mathrm{PP}+$ & 0.148 & 0.063 & 1.16 & $1.02,1.31$ & 0.02 \\
\hline $0 \mathrm{PP}$ vs. $100 \mathrm{PP}$ & 0.171 & 0.064 & 1.19 & $1.05,1.35$ & 0.008 \\
\hline $0 \mathrm{PP}$ vs. $100 \mathrm{PP}+$ & 0.364 & 0.075 & 1.44 & $1.24,1.67$ & $<0.001$ \\
\hline $33 \mathrm{PP}$ vs. $33 \mathrm{PP}+$ & -0.163 & 0.080 & 0.85 & $0.73,0.99$ & 0.04 \\
\hline $33 \mathrm{PP}$ vs. $66 \mathrm{PP}$ & -0.299 & 0.076 & 0.74 & $0.64,0.86$ & $<0.001$ \\
\hline $33 \mathrm{PP}$ vs. $66 \mathrm{PP}+$ & -0.250 & 0.078 & 0.78 & $0.67,0.91$ & 0.002 \\
\hline $33 \mathrm{PP}$ vs. $100 \mathrm{PP}$ & -0.140 & 0.081 & 0.87 & $0.74,1.02$ & 0.08 \\
\hline $33 \mathrm{PP}+$ vs. $66 \mathrm{PP}$ & -0.136 & 0.066 & 0.87 & $0.77,0.99$ & 0.04 \\
\hline $33 \mathrm{PP}+$ vs. $100 \mathrm{PP}+$ & -0.086 & 0.080 & 1.24 & $1.06,1.45$ & 0.007 \\
\hline $66 \mathrm{PP}$ vs. $100 \mathrm{PP}$ & 0.023 & 0.067 & 1.17 & $1.03,1.34$ & 0.02 \\
\hline $66 \mathrm{PP}$ vs. $100 \mathrm{PP}+$ & 0.216 & 0.077 & 1.42 & $1.22,1.65$ & $<0.001$ \\
\hline $66 \mathrm{PP}+$ vs. $100 \mathrm{PP}+$ & 0.050 & 0.079 & 1.35 & $1.16,1.58$ & 0.001 \\
\hline $100 \mathrm{PP}$ vs. $100 \mathrm{PP}+$ & 0.159 & 0.081 & 1.21 & $1.03,1.42$ & 0.02 \\
\hline
\end{tabular}

${ }^{1}$ Fecal score $\geq 3$ (1 to 4 scale).

${ }^{2}$ Treatments: $0 \mathrm{PP}=$ control; $33 \mathrm{PP}=33 \%$ spray-dried bovine plasma protein $(\mathrm{PP}) ; 33 \mathrm{PP}+=33 \% \mathrm{PP}+\mathrm{Ile}$; $66 \mathrm{PP}=66 \% \mathrm{PP} ; 66 \mathrm{PP}+=66 \% \mathrm{PP}+\mathrm{Ile} ; 100 \mathrm{PP}=100 \% \mathrm{PP} ; 100 \mathrm{PP}+=100 \% \mathrm{PP}+$ Ile. All other comparisons not shown were not significant $(P>0.10)$.

${ }^{3}$ The odds ratio (OR) indicates the probability of scours for the first treatment in comparison to the second treatment. If the OR was $>1$, the first treatment in the comparison was more likely to have scours than the second treatment by a factor of the difference above 1 . If the OR was $<1$, the variable had a lower probability of occurring for the first treatment than for the second treatment. 


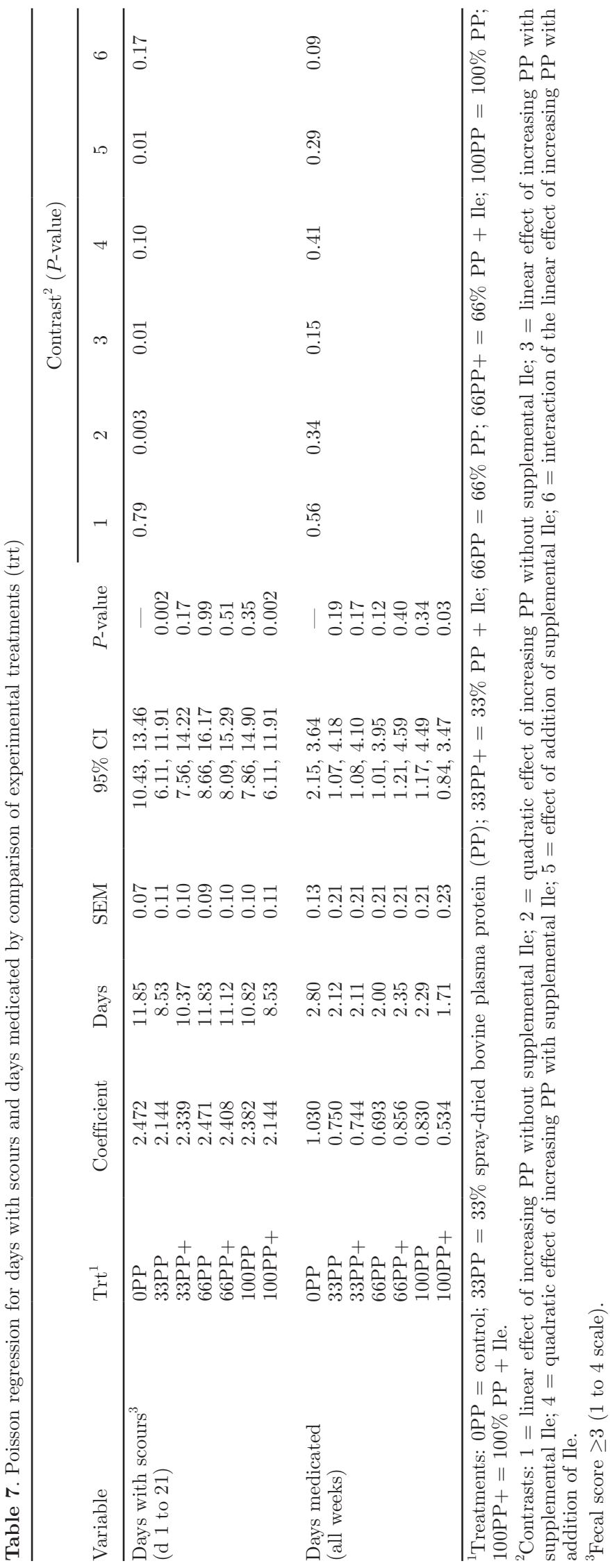

which caused differences in Lys intake. For example, Lys intake was almost $1 \mathrm{~g} / \mathrm{d}$ greater for calves fed $66 \mathrm{PP}+$ than for those fed 66PP, and ADG was $46 \mathrm{~g} / \mathrm{d}$ greater for calves fed $66 \mathrm{PP}+$ than for those fed $66 \mathrm{PP}$. However, calves fed 100PP and 66PP had similar Lys intakes, but $\mathrm{ADG}$ for 100PP lagged behind that of $66 \mathrm{PP}$ by $60 \mathrm{~g} / \mathrm{d}$. Indeed, calves fed $100 \mathrm{PP}+$ had the lowest Lys intake of all treatments, yet had ADG only $23 \mathrm{~g} / \mathrm{d}$ less than calves fed 66PP. If Lys is the limiting EAA for growth, as assumed, values for gain-Lys ratio may help to differentiate the effects of variable Lys intake from those of AA balance or other factors. The gain-Lys ratio was similar for $0 \mathrm{PP}, 33 \mathrm{PP}$, and $33 \mathrm{PP}+$, but was substantially lower for $66 \mathrm{PP}$, regardless of Ile supplementation. The efficiency of Lys use declined further with 100PP, but supplementation of Ile returned gain-Lys ratio to a value slightly higher than for $66 \mathrm{PP}$ or $66 \mathrm{PP}+$. The largest difference in AA profile between $100 \mathrm{PP}$ and $100 \mathrm{PP}+($ Table 4$)$ was in relative Ile content (58 for $100 \mathrm{PP}+$ vs. 38 for $100 \mathrm{PP}$ ), with Ile for $100 \mathrm{PP}$ being well below the estimated optimal concentration. We speculate that the results may be consistent with a greater effect of EAA profile relative to Lys intake than with dietary Lys intake per se.

Spray-dried PP provides a mixture of functional components that are biologically active in the intestine and are thought to aid in the maintenance of normal intestinal barrier function (Campbell et al., 2010). The IgG proteins in plasma and serum are only partially digested in the gut; the remaining portion remains biologically active and supports the host system through localized passive immunity (Roos et al., 1995). Plasma protein is widely used in the swine industry to improve the health of young piglets, specifically during times of stress, such as weaning (Torrallardona, 2010). The inclusion of PP in weaned pig diets has been shown to improve intestinal barrier function, decrease mucosal inflammation, and decrease diarrhea, but the mechanism of action remains unclear (Peace et al., 2011). Variability in response of growth parameters is thought to be attributable to the amount of $\mathrm{PP}$ included in the diet and to the environment of the pigs. A review by Torrallardona (2010) showed beneficial results when PP was included at 4 to $8 \%$ of the diet; at higher inclusions, the responses were variable, likely dependent on the Ile content of the diet. Coffey and Cromwell (1995) showed improved growth in pigs fed PP when they were housed in conventional systems that had a greater pathogen load and level of exposure compared with more controlled environments.

The incorporation of PP into calf diets improved measures of health in our study, similar to results from previous studies with young calves. Quigley et al. (2002) and Quigley and Wolfe (2003) observed decreased mor- 
tality and morbidity in calves fed low inclusion rates (5\% of the diet; $25 \%$ replacement of protein) of spraydried animal PP. Similarly, calves that were challenged with enteric pathogens and fed a biologically active form of IgG from plasma showed reduced mortality (Quigley and Drew, 2000; Arthington et al., 2002; Hunt et al., 2002). In this trial, we found that calves fed the lowest inclusion of PP (33\%) and the highest inclusion of PP $(100 \%)$ had a lower probability of having scours and fewer days of scours than those fed the all-milk control, resulting in lower mortality.

In rats, an imbalance of branched-chain AA in the diet can result in impairment of immunity, especially with a low-protein diet (Aschkenasy, 1979). A similar effect may partially explain the reduction in average days with scours and average amounts of electrolyte administration when Ile was added to diets containing PP in our study. We speculate that with supplemented Ile, the balance of EAA was improved, allowing the calves to have an improved immune response to sickness and reducing the severity of a challenge. However, more research is needed in this area to fully elucidate the effects of balanced branched-chain AA on dairy calf health.

We observed few effects on blood metabolites related to $\mathrm{N}$ metabolism in this study. As expected, calves fed the diet with $100 \%$ of the replaceable $\mathrm{CP}$ as PP without Ile supplementation had the lowest ADG, final size measurements, and gain-feed ratio. Despite this poorer growth performance, however, serum protein concentrations in this group did not differ from those in other groups. Concentrations of urea $\mathrm{N}$ were greater for calves fed $66 \mathrm{PP}, 66 \mathrm{PP}+$, and $100 \mathrm{PP}$, but were sharply lower for calves fed 100PP + . The latter may reflect the improved EAA profile from Ile supplementation when dietary Lys intake was lowest. Urea N concentrations were low in general, likely because of the limited CP supply and the fact that no starter was fed during the study.

Supplementation with Ile tended to reverse or lessen many of the negative effects of high rates of PP inclusion. Other EAA that decreased in relative proportion to Lys as PP increased (such as Thr, Leu, and Val) may have become more limiting at higher rates of $\mathrm{PP}$ inclusion. The effects of EAA balance at high PP inclusion rates warrant further investigation. Moreover, because the feeding rate and ADG in this study were far below values that would approach maximum growth, it would be of interest to determine the effects of high PP inclusion and EAA balance in calves fed to achieve high rates of gain. Such effects are difficult to predict from our results, but the importance of EAA balance is well known from studies conducted in rapidly growing pigs (van Dijk et al., 2001).

\section{CONCLUSIONS}

Previous research has indicated that $\mathrm{PP}$ is a viable alternative protein source when supplemented to provide $25 \%$ or less of total dietary CP. Our findings support that conclusion. Growth rates and gain-feed ratio were decreased at inclusion rates $>33 \%$ of the dietary CP. More important, however, was our finding that replacement of essentially all of the whey proteins in the diet with PP plus Ile supplementation resulted in ADG only 31\% lower than in calves fed the all-milkprotein control diet. Even at the highest inclusion rate, the addition of PP supported enhanced enteric health, in marked contrast to results with most other alternative protein sources. Additional titration studies would be needed to more closely determine the PP inclusion rate at which performance begins to be compromised, and which $\mathrm{AA}$ at what concentrations are needed to maintain growth and health in calves similar to MR containing all milk proteins. Diets in which greater amounts of PP are included to replace whey proteins should include supplemental Ile as well as Met after balancing for Lys; the possibility that other EAA also become limiting should be explored.

\section{ACKNOWLEDGMENTS}

This study was supported by state and federal (USDA-CSREES) funds appropriated to the Illinois Agricultural Experiment Station, and by APC Inc. (Ankeny, IA). The authors extend appreciation to Milk Specialties Co. (Eden Prairie, MN) for the manufacture and donation of the milk replacers and Land O'Lakes (St. Paul, MN) for donation of the electrolytes.

\section{REFERENCES}

Arthington, J. D., C. A. Jaynes, H. D. Tyler, S. Kapil, and J. D. Quigley III. 2002. The use of bovine serum protein as an oral support therapy following coronavirus challenge in calves. J. Dairy Sci. $85: 1249-1254$.

Aschkenasy, A. 1979. Prevention of the immunodepressive effects of excess dietary leucine by isoleucine and valine in the rat. J. Nutr. 109:1214-1222.

Campbell, J. M., J. Polo, L. E. Russell, and J. D. Crenshaw. 2010. Review of spray-dried plasma's impact on intestinal barrier function. Livest. Sci. 133:239-241.

Coffey, R. D., and G. L. Cromwell. 1995. The impact of environment and antimicrobial agents on the growth response of early-weaned pigs to spray-dried porcine plasma. J. Anim. Sci. 73:2532-2539.

Davis, C. L., and J. K. Drackley. 1998. The Development, Nutrition, and Management of the Young Calf. Iowa State University Press, Ames.

Hunt, E., Q. Fu, M. U. Armstrong, D. K. Rennix, D. W. Webster, J. A. Galanko, W. Chen, E. M. Weaver, R. A. Argenzio, and J. M. Rhoads. 2002. Oral bovine serum concentrate improves cryptosporidial enteritis in calves. Pediatr. Res. 51:370-376.

Morrill, J. L., J. M. Morrill, and A. M. Feyerherm. 1995. Plasma proteins and a probiotic as ingredients in milk replacer. J. Dairy Sci. 78:902-907. 
NRC. 2001. Nutrient Requirements of Dairy Cattle. 7th rev. ed. Natl. Acad. Press, Washington, DC.

Peace, R. M., J. Campbell, J. Polo, J. Crenshaw, L. Russell, and A. Moeser. 2011. Spray-dried porcine plasma influences intestinal barrier function, inflammation and diarrhea in weaned pigs. J. Nutr. 141:1312-1317.

Quigley, J. D., III, and J. K. Bernard. 1996. Milk replacers with or without animal plasma for dairy calves. J. Dairy Sci. 79:1881-1884.

Quigley, J. D., III, and M. D. Drew. 2000. Effects of oral antibiotics or IgG on survival, health, and growth in dairy calves challenged with E. coli. Food Agric. Immunol. 12:311-318.

Quigley, J. D., III, C. J. Kost, and T. A. Wolfe. 2002. Effects of spraydried animal plasma in milk replacers or additives containing serum and oligosaccharides on growth and health of calves. J. Dairy Sci. 85:413-421.

Quigley, J. D., III, and T. M. Wolfe. 2003. Effects of spray dried animal plasma in calf milk replacer on health and growth of dairy calves. J. Dairy Sci. 86:586-592.

Roos, N., S. Mahé, R. Benamouzig, H. Sick, J. Rautureau, and D. Tomé. 1995. ${ }^{15} \mathrm{~N}$-Labeled immunoglobulins from bovine colostrum are partially resistant to digestion in human intestine. J. Nutr. $125: 1238-1244$

Torrallardona, D. 2010. Spray dried animal plasma as an alternative to antibiotics in weanling pigs. A review. Asian-australas. J. Anim. Sci. 23:131-148.

USDA. 2012. Dairy Heifer Raiser, 2011. \#613.1012. USDA-APHISVS-CEAH-NAHMS, Fort Collins, CO.

Van Amburgh, M. E., E. A. Collao-Saenz, R. J. Higgs, D. A. Ross, E. B. Recktenwald, E. Raffrenato, L. E. Chase, T. R. Overton, J. K. Mills, and A. Foskolos. 2015. The Cornell Net Carbohydrate and Protein System: Updates to the model and evaluation of version 6.5. J. Dairy Sci. 98:6361-6380.

van Dijk, A. J., H. Everts, M. J. A. Nabuurs, R. J. C. F. Margry, and A. C. Beynen. 2001. Growth performance of weanling pigs fed spray-dried animal plasma: A review. Livest. Prod. Sci. 68:263-274.

Williams, A. P., and D. Hewitt. 1979. The amino acid requirements of the preruminant calf. Br. J. Nutr. 41:311-319. 